\title{
Nyudvikling af projektarbejdsformen på RUC - beskrivelse og analyse af et eksperiment: "Antologieksperimentet"
}

\author{
Sфren Dupont, lektor, Institut for Psykologi og Uddannelsesforskning, \\ $R U C$. \\ Artiklen beskriver og analyserer et undervisningseksperiment ved RUC, \\ som udvider og udvikler projektpædagogikken i felterne mellem den enkel- \\ te projektdeltager og de fxlles grupperinger, som studerende indgår $i$ på \\ RUC. Der redegøres for projektets opbygning omkring en klyngestruktur, \\ og der knyttes an til laringsteoretikerne Etienne Wenger og Donald \\ Schön. Desuden inddrages aktionsforskning.
}

\begin{abstract}
"Gensidige relationer mellem deltagere er i det virkelige liv komplekse blandinger af magt og afhængighed, lyst og smerte, ekspertise og hjælpeløshed, succes og fiasko, overflod og afsavn, alliance og konkurrence, velvære og kamp, autoritet og kollegialitet, modstand og eftergivenhed, vrede og ømhed, tiltrækning og modvilje, sjov og kedsomhed, tillid og mistænksomhed, venskab og had. Praksisfællesskaber har det hele". (Wenger, 2004: 95)
\end{abstract}

Ved forårssemestrets begyndelse i 2011 blev et eksperiment og forsøg med udvikling af projektarbejdsformen ved RUC sat på skinner ved studiet Arbejdslivsstudier, som er et tværfagligt og tværvidenskabeligt samarbejde mellem forskellige faglige miljøer ved RUC: Pædagogik, TekSam, Psykologi og Virksomhedsstudier.

Den gængse projektarbejdsform ved RUC udgøres af den enkelte projektgruppe, hvortil der er knyttet en vejleder, som følger gruppen gennem projektforløbet ofte gennem et semester. Det er formentlig unikt ved RUC som universitet, at stort alle studerende hvert år begynder deres studier med dannelse af projektgrupper. Det skyldes, at $50 \%$ af undervisningen ved RUC skal gennemføres i projektarbejdsformen.

RUC har i snart 40 år koncentreret sig om at sætte den studerende i centrum, at skabe studentercentreret læring. Det er RUC ikke blevet verdensberømt for; det er derimod 
den australske psykolog og forfatter John Biggs. Han har gjort sig til talsmand for en teori, der hviler på et grundlag, som kaldes for 'constructive alignment'.

Der er to områder, der er centrale at fremhæve inden for constructive alignment/tilpasning:

- De studerende konstruerer mening ud af det, de gør for at lære.

- Læreren/vejlederen tilbyder rammer for den planlagte læring og de planlagte læringsresultater.

Ud over constructive alignment er Biggs nok mest kendt for at have udviklet den såkaldte SOLO-taksonomi. Denne kan ifølge Biggs bruges til at vurdere kvaliteten af læringsresultater.

Constructive alignment optræder første gang hos Biggs i 1999. Den bog fra Biggs hånd, der har haft størst indflydelse på udviklingen universitetsundervisning, er nok "Teaching for Quality Learning at University", der er udkommet i tredje udgave med Catherine Tang som medforfatter.

Siden 1999 har Biggs' teori været anvendt i store dele af den universitetspædagogiske forskning over det meste af verden - også i Danmark. Biggs' teori er langt fra uden problemer, og den bør såvel kritiseres som udvikles. Hanne Leth Andersen, prorektor ved RUC, har i artiklen 'Constructive alignment' og risikoen for en forsimplende Universitetspædagogik" såvel anerkendt som kritiseret Biggs. Man kan sige, at RUC udvider Biggs bl.a. ved, at det på RUC ikke blot drejer sig om at sætte den enkelte student $\mathrm{i}$ centrum men om at sætte studentergruppen i centrum.

Sat op i en idealform forløber det gængse projektforløb på RUC ved basisstudierne og i bachelorstudierne på følgende måde: 


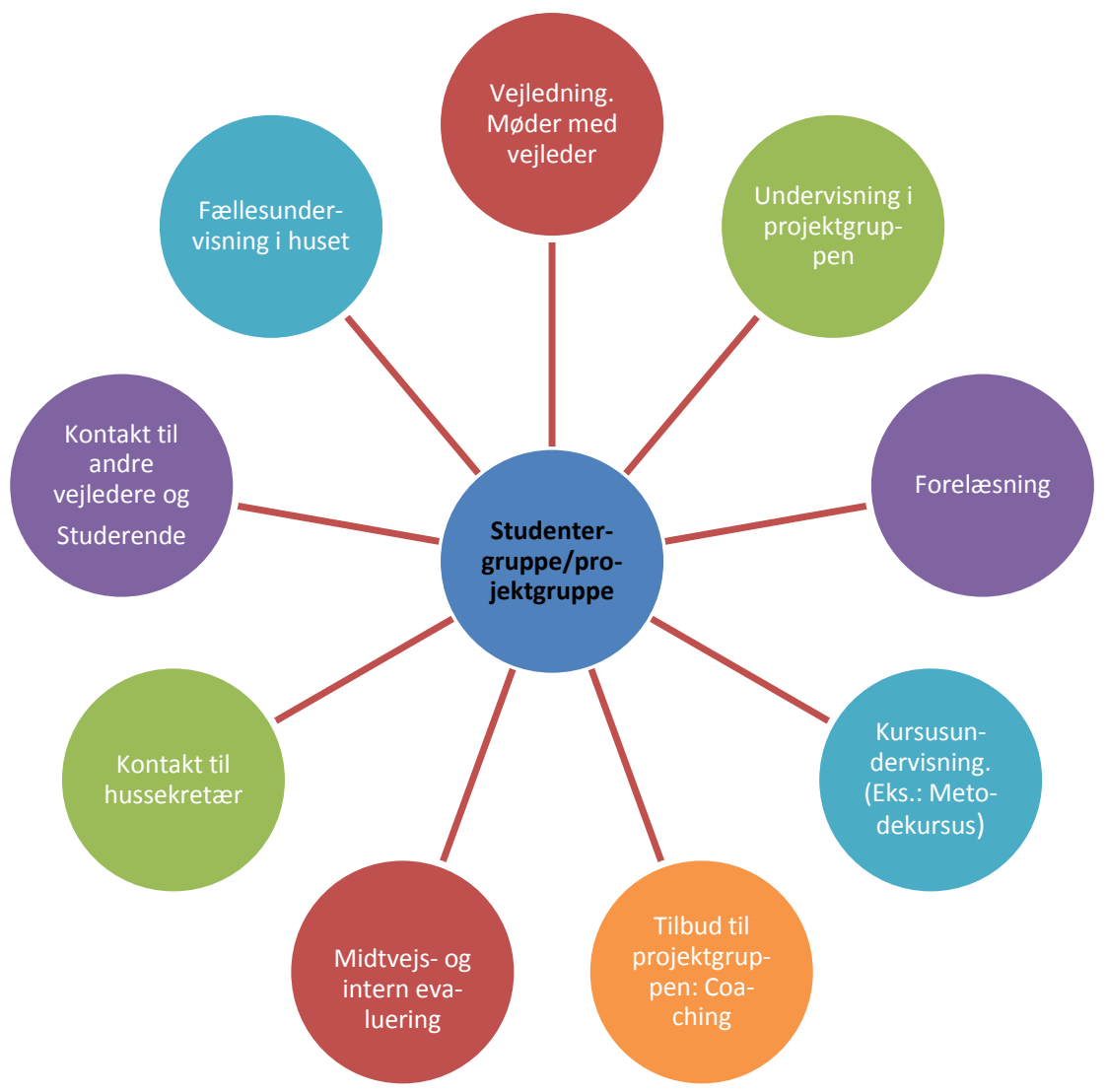

Figur 1: Idealtype for projektforløb på RUC

Det nye i det såkaldte antologiprojekt blev især, at flere grupper på samme tid i et fælles forløb hen over ét semester blev sat i centrum. I de fleste andre projektforløb på RUC er det den enkelte projektgruppe, der er sat i centrum. I antologiprojektet blev der skabt rammer for, at flere projektgrupper på samme tid og i et fælles forløb, kom til at arbejde sammen.

\section{Antologieksperimentet og dets opbygning}

I gennem efterårssemesteret 2010 havde underviserne og de studerende sammen $\mathrm{i}$ mindre skala forsøgt sig med enkeltstående små forsøg og eksperimenter, og det blev besluttet fra forårssemestret 2011 at starte et større eksperiment med intention om at bidrage til fornyelsen af projektpædagogikken ved RUC, bl.a. fordi mange studerende oplever en vis træthed og ambivalens i forhold til den gængse projektarbejdsform, især når de studerende begynder på kandidatuddannelserne ved RUC. De studerende har på dette tidspunkt gennemført 7-8 meget omfattende projektforløb, og derfor oplever flere studerende behov for fornyelse. Derfor skønnede en række lærere ved studiet Arbejdslivsstudier, at et udkast til fornyelser ville være på sin plads. 
På RUC har rektor en såkaldt "Udviklingspulje", der ifølge vedtægterne blandt andet skal anvendes til udvikling, forsøg og eksperimenter. Det blev fra lærergruppens og studenternes side besluttet at søge i denne pulje, og eksperimentet blev understøttet med et større beløb, ligesom der blev bevilget økonomi til en omfattende evaluering af projektet, som skulle gennemføres af UniPæd (Den universitetspædagogiske enhed ved RUC). Evalueringen blev bygget op over en række observationer, 2 fokusgruppeinterview med de studerende, et spørgeskema til alle de studerende, et spørgeskema til censorerne samt andet materiale, der er indgået i kurset.

I slutningen af januar 2011 blev der afholdt møde med de studerende på det såkaldte K1-modul, som er det første modul på Arbejdslivsstudier efter bachelorgraden. På mødet blev grundstrukturen i projektet præsenteret, men der manglede noget. Det var ikke helt muligt at samle eksperimentet i en overskift/titel - indtil en studerende udbrød:

"Jamen det skal da hedde "Antologieksperimentet".

Hermed blev der leveret en metafor, som samlede en stor del af intentionerne i projektet, som bl.a. var orienteret mod det at arbejde med en såkaldt klyngestruktur i projektarbejdet.

En klynge kan i forhold til projektarbejde skitsemæssigt opregnes som nedenfor, hvor der med udgangspunkt i klyngens deltagere dannes en række projekter/projektgrupper, hvortil der er tilknyttet såvel kurser, som læsegrupper og forelæsninger alt sammen med inddragelse af de ønsker, de studerende i samspil med vejlederne måtte have.

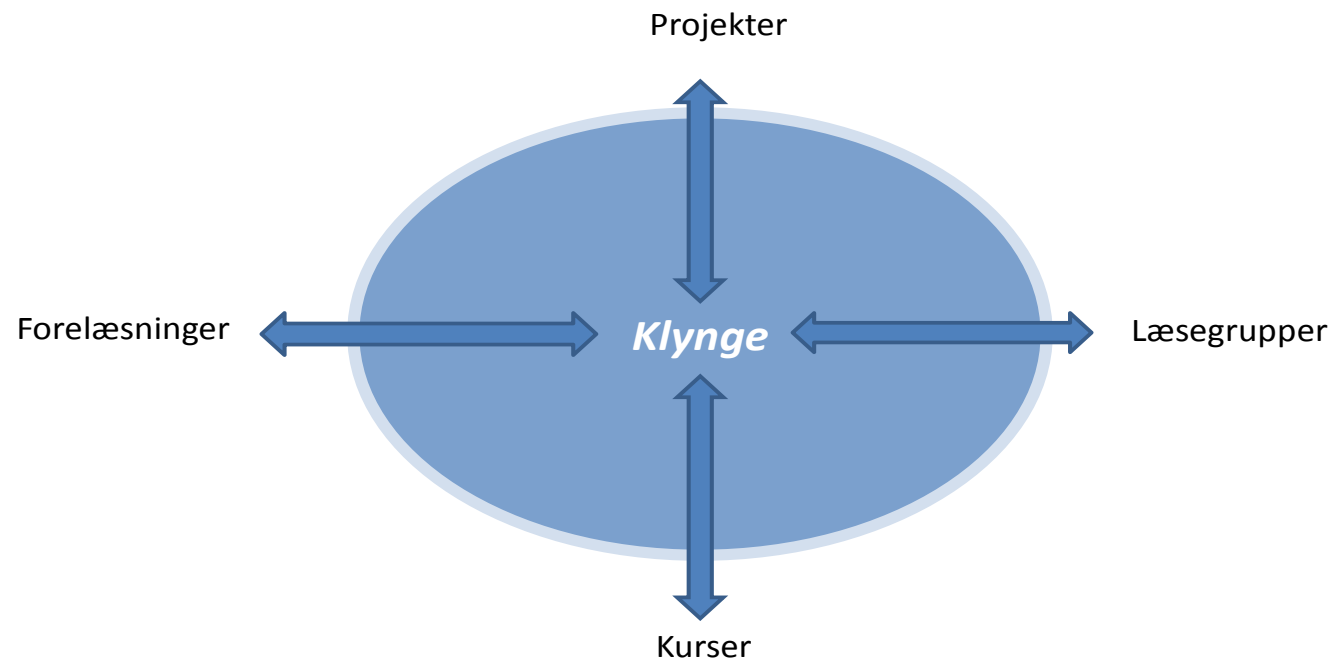

Figur 2: Den traditionelle klyngestruktur på RUC 
En klynge kan defineres som:

1. En enhed af undervisere og studerende, som ikke kun er én projektgruppe.

2. En samling af forskellige undervisnings- og læringsformer: eksperimenter, forelæsninger, kurser, diskussioner, ekskursioner etc.

Der har på RUC været eksperimenteret med mange forskellige elementer i klyngestrukturen.

Thomas Gitz-Johansen, Kim Rasmussen og Trine Wulf-Andersen, alle tilknyttet Institut for Psykologi og Uddannelsesforskning ved RUC, skriver i den forbindelse om klyngeundervisning, at den "er tænkt som en undervisningsform, der på en gang søger at understøtte projekterne, give breddeviden og større overblik, samt lade projektgruppedeltagerne indgå i en anden og social kontekst end projektgrupperne selv gestalter." (Wulf-Andersen et al., 2007: 34).

I "Antologieksperimentet" ved Arbejdslivsstudier blev selve strukturen i projektet/eksperimentet fastlagt som skitseret nedenfor:

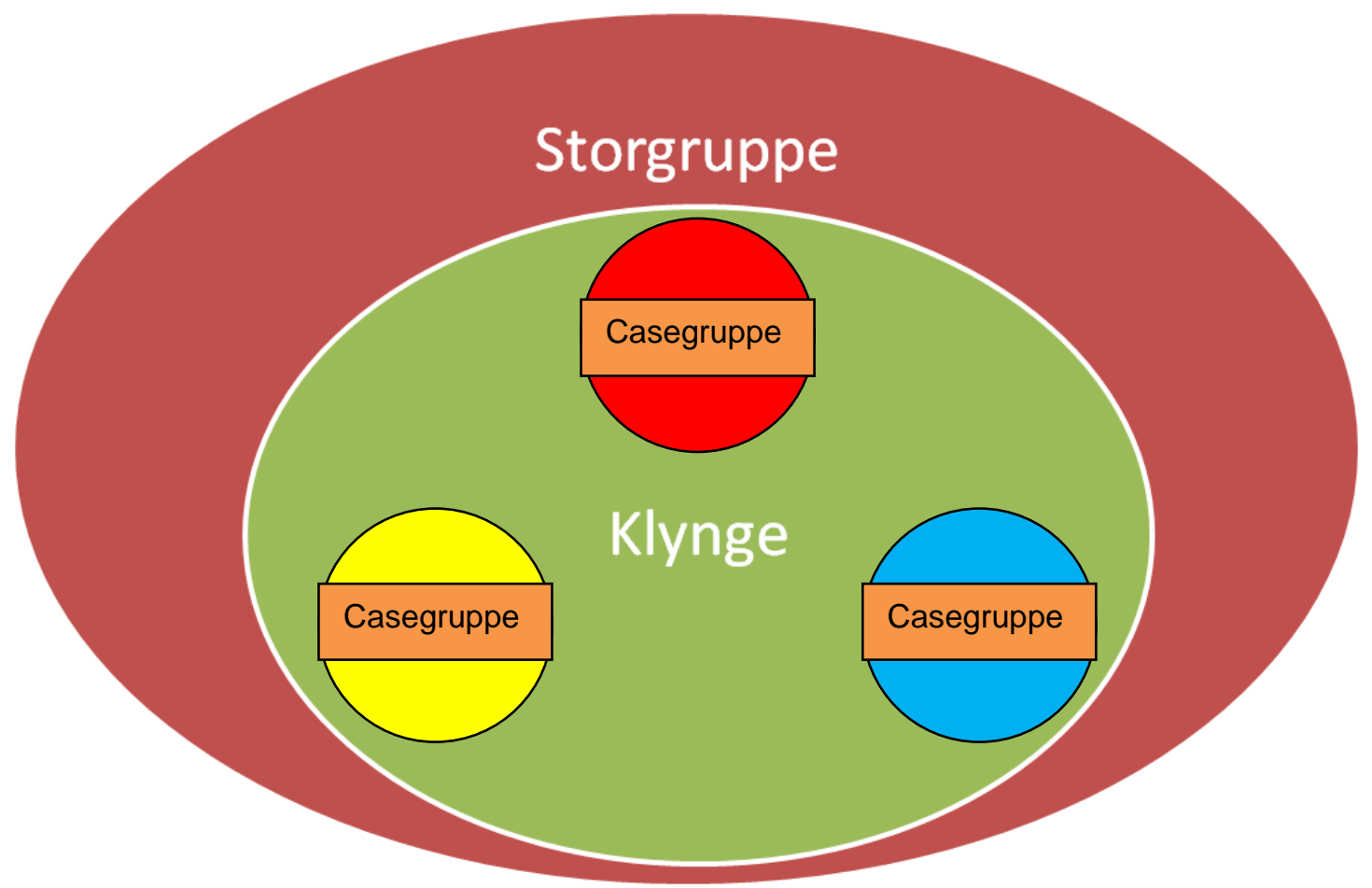

Figur 3: Antologiprojektets opbygning 
Her udgør storgruppen det samlede antal studerende på kandidatmodulet. Storgruppen bestod af 52 studerende.

Med udgangspunkt i storgruppen blev der derefter dannet 4 klynger i en gruppedannelsesproces. Den fælles overskrift på gruppedannelsesprocessen, som de studerende alle skulle forholde sig til, var: Forandring og involvering i forandring. Med udgangspunkt heri arbejdede de studerende sig - med støtte fra sidelinjen fra vejlederne - frem mod en række temaer, som en gruppe studerende (altså en klynge af studerende) ville arbejde med. På den baggrund blev der dannet 4 klynger med følgende temaer/overskrifter/titler:

1. Demokratisering og forandringsprocesser.(14)

2. På vej mod det gode arbejde. (17)

3. Bæredygtig innovation. (14)

4. Faglighed i forandring. (7)

Parenteserne viser hvor mange studerende, der var i den enkelte klynger.

Det skal understreges, at antologiprojektet udgjorde det samlede studieforløb for de studerende gennem et helt semester. Projektet udgjorde således 30 ECTS point.

Herefter blev der inden for de enkelte klynger dannet en række casegrupper, som på caseagtig vis arbejdede med de ovennævnte klyngers overskrifter.

Der var tilknyttet to kurser til modulet. Kurserne understøttede på forskellig vis arbejdet i klyngerne og casegrupperne. Det ene kursus omfattede tematikken "Arbejdslivets problemstillinger og de nye reguleringsformer" og det andet kursus arbejdede under overskriften: "Forandringsprocesser og forandringsmetoder i arbejdslivet". I begge kurser indgik der såvel videnskabsteoretiske som metodiske problemstillinger.

Vejledergruppen opfordrede til, at de enkelte klynger diskuterede ledelse og arbejdsformer i klyngen. Dette blev endvidere betragtet som en god øvelse i forhold til de arbejdsformer, de studerende kunne forvente at møde på arbejdsmarkedet efter deres kandidateksamen.

Det blev også fremhævet som væsentligt, at de enkelte klynger og casegrupper diskuterede hvilke forventninger, de måtte have til vejlederens rolle i forløbet. Det fremgår af den efterfølgende evaluering, at denne del af projektet ikke blev gennemført i tilstrækkeligt omfang. Det er beklageligt, da det er her nogle af de største udfordringer på vejledersiden/lærersiden lader sig identificere. Mere om dette lidt senere. 
De studerende blev endvidere opfordret til at gøre sig klart, hvad der skulle fastlægges af retningslinjer for hvad, der som minimum skulle ydes af arbejdsindsats af den enkelte for at kunne deltage i gruppens arbejde.

I projektet blev klyngen gjort ansvarlig for det samlede produkt, men det meste materiale blev produceret i undergrupper - i casegrupperne. Det fratog dog på ingen måde klyngen for ansvaret, snarere tværtimod, det forstærkede og udbyggede det samlede ansvar, som klyngen havde. Der blev holdt ugentlige møder i klyngerne, hvor alle casegrupperne altså mødtes og diskuterede på tværs af casegrupperne i klyngen. Vejlederne/lærerne deltog ofte i disse møder.

\section{Antologien}

I de enkelte klynger skulle de mindre casegrupper hver for sig udvikle og arbejde med en case under det overordnede tema for klyngen, men selvfølgelig med forskellige tilgange og med forskellige tematikker bragt i spil.

Klyngen skulle producere en antologi bestående af bidrag fra alle de enkelte casegrupper. På den måde skulle antologien bygges op over casegruppernes forskellige bidrag til antologien

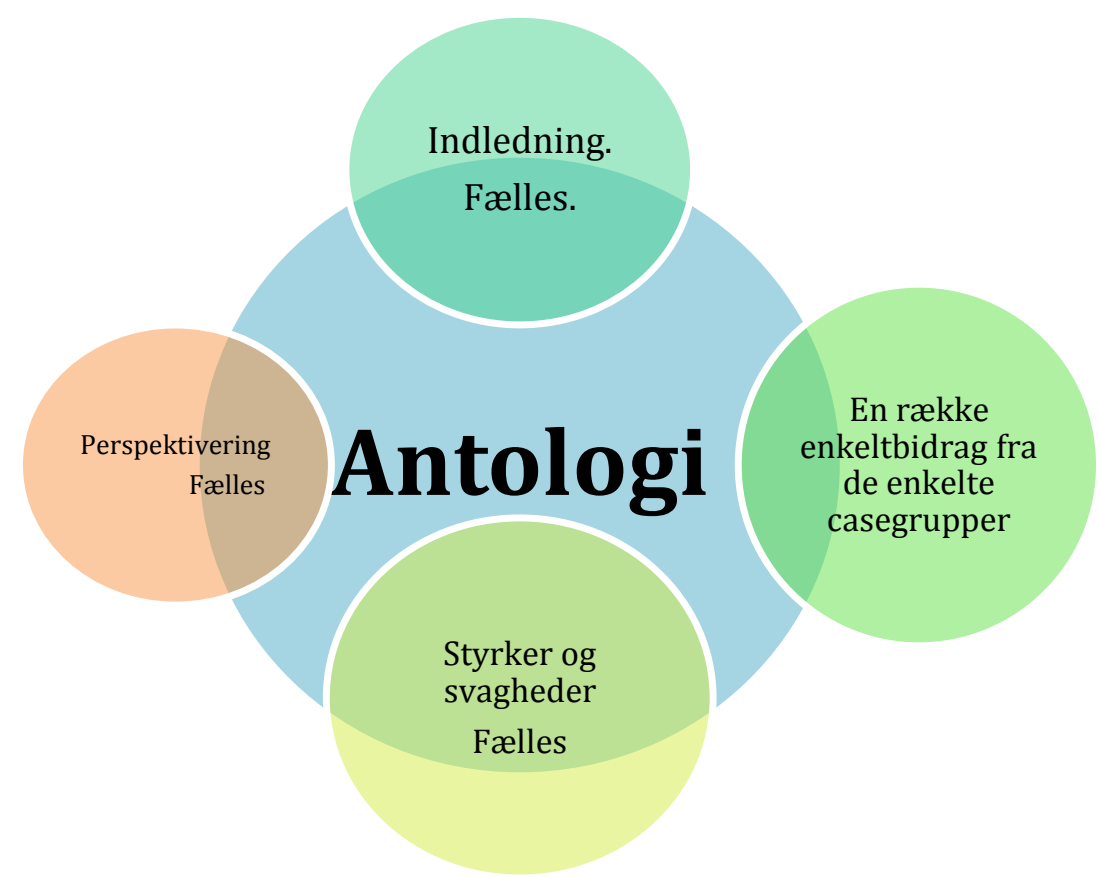

Figur 4: Antologiens opbygning i antologiprojektet 
Antologien skulle fra forskellige vinkler belyse specifikke forandringer og involveringer i arbejdslivet. Det involverede både teoretiske og empiriske studier og kritisk distance, metodisk refleksion, og frem for alt så udfordredes i høj grad evnen til samarbejde mellem de enkelte studerende i casegrupperne, casegruppens relation til klyngen og de fælles relationer mellem alle casegrupperne i klyngen. Sagt på en anden måde: Forholdet mellem den enkelte studerende og frllesskaberne blev virkelig sat på prøve og til udvikling.

De studerende skulle altså ikke blot tænke og agere i forhold til en enkelt projektgruppe, de skulle tænke på tværs af projektgrupper og med udgangspunkt heri producere et fælles produkt som rakte ud over det enkelte projekt.

Antologien måtte max fylde 200 sider. Der blev opfordret til, at de studerende i forhold til antologien nedsatte en redaktionsgruppe og diskuterede, hvilke beføjelser denne gruppe skulle have. En vanskelighed, de eksempelvis skulle tage stilling til, kunne være, hvordan de enkelte casegruppers indspil til antologien skulle bearbejdes i forhold til en fælles linje: Indledning, evt. teori, evt. metode, rød tråd, afslutning, beskrivelse af de enkelte gruppers bidrag etc. Alt dette for at skabe større sammenhæng i processen.

Af disse årsager blev det også forventet, at klyngen undervejs i processen udarbejdede en logbog, der indeholdt de løbende erkendelser under casearbejdet. Logbogen kunne også tjene som grundlag for den fremadrettede planlægning af opgaver og kunne bruges til at afdække, hvor klyngen stod og hvilken vejledning, der var brug for.

Da formidling spiller en central rolle i det pågældende studiemodul - K1 - blev der lagt op til at reflektere over, hvordan viden evt. kunne deles internt i klyngen, med vejlederen, i casegruppen, med de andre klynger og til eksamen. Det blev anbefalet, at der i antologien blev produceret et afsnit om, hvordan klyngearbejdet var gået, set i et læringsperspektiv. De studerende udnyttede og arbejdede med dette på forskellig vis. Flere ting blev anvendt, blandt andet logbog, referater af møder, fremtidsværkstedet og forskellige it-bårne redskaber til at skabe vidensdeling, herunder facebook, hvor de studerende løbende har indgået aftaler, diskuteret og således har brugt facebook som et socialt redskab. Endelig har de studerende opfattet den del af evalueringen, der bestod af fokusgruppeinterview, som en god anledning til at få reflekteret over egen læring.

\section{Eksperimentets læringsmål}

Det overordnede formål med eksperimentet var som allerede nævnt at komme tæt på forandringsprocesser i arbejdslivet, hvor forståelse af konteksten er central. 
Lærergruppen bag eksperimentet definerede en række læringsmål for "Antologiprojektet". De lød som følger:

1. Etablere et kritisk analytisk perspektiv på forandringsprocesser og:

2. Få indsigt i og opøve erfaringer med at få en stor kompleks projektgruppe til at fungere

Hertil kom en række praktiske målsætninger, der lød som følger:

1. Skabe mulighed for, at projektgrupperne kan involvere sig tidligt $\mathrm{i}$ forandringsarbejde.

2. Skabe et tættere studiemiljø.

3. Udvikle studenternes projekterfaringer.

Vi kan til læringsmål og praktiske mål ovenfor her tilføje, at intentionen fra undervisernes/vejledernes side også har været at forbedre undervisningen ved hjælp af forandring, sætte nye handlingsformer i spil, nye problemløsningsrelationer, og selvfølgelig også muligheden for, at de studerende på baggrund af egen aktivitet udvikler ny, teoretisk viden. For så vidt er dette alt sammen ikke forskelligt fra, hvad der "normalt" sker i projektarbejdet på RUC, men formen har været en ganske anden, hvor langt flere studerende er kommet i faglig og social kontakt med hinanden.

En særlig opmærksomhed var der på eksamen, hvor en synopsis, der var individuelt produceret, kom til at udgøre rammen. Synopsens omfang blev fastlagt til to sider.

De studerende var altså ansvarlige for hele antologien, den var pensum for de studerendes eksamen, men eksamen blev sporet af den individuelle synopsis. De studerende var i forhold til den individuelle synopsis ikke bundet af deres egen case i antologien, de kunne vælge deres temaer i synopsen frit i forhold til det genstandsfelt, der blev behandlet i antologien. Antologien udgjorde rammen for eksaminationen og synopsen udgjorde retningen. ${ }^{1}$

\footnotetext{
${ }^{1}$ Lærerkollegiet har oplyst til de studerende at antologien vil blive vurderet ud fra følgende kriterier og parametre: "Arbejdets omfang, selvstændighedsgraden af arbejdet, originaliteten i arbejdet, de læringsprocesser der kommer til udtryk gennem arbejdet samt kvaliteten af anvendelsen af metodiske og teoretiske perspektiver. Der er ligeledes krav til at klyngen deltager i midtvejsseminaret og fremlægger perspektiver fra emnearbejdet ved evalueringsseminaret." Såvel midtvejsevalueringen som evalueringsseminaret er former for udviklingsdimensioner i projektarbejdet på RUC. Det findes ikke alle steder, men det eksisterer bl.a. ved Arbejdslivsstudier. I begge tilfælde arbejder studerende og vejledere sammen om at kritisere, udvikle og perspektivere studenternes arbejde i løbet af den samlede projektfase.
} 
I evalueringen påpegede de studerende, at usikkerheden omkring denne synopsis og dens indhold var for stort. Den sidemæssige begrænsning besværliggjorde udarbejdelsen af synopsen, og det var vanskeligt for de studerende at finde ud af, hvad vejleder og censor forventede af synopsen. Men resultatet blev godt modtaget af både vejledere og censorer, og karaktererne lå i den absolut høje ende: 20 studerende fik 12, 24 studerende fik 10 og 8 studerende fik karakteren 7.

\section{Antologieksperimentet og aktionsforskning}

Man kan argumentere for, at en væsentlig linje i eksperimentet er rettet mod aktionsforskningen. Der blev i det ene af kurserne, som var tilknyttet eksperimentet, lagt vægt på aktionsforskning, og der kan trækkes linjer til aktionsforskningens grundlag, når projektet anskues ud fra de studerendes synspunkt. Her spiller Donald Schöns begreb om den reflekterende praktiker en væsentlig rolle - både i forhold til de studerendes refleksion $i$ handling og i forhold til de studerendes refleksion over handling. Hvad angår refleksion $i$ handling hedder det hos Schön:

"Vores viden ligger som regel indbygget $\mathrm{i}$ vores handlemønstre og i vores fornemmelse for den materie, vi har med at gøre. Det forekommer korrekt at sige, at vores viden ligger i vores handlinger". (Schön, 2001: 51).

For Schön og for Antologieksperimentet bliver det herefter centralt at reflektere over disse handlinger, altså skabe refleksion ikke bare $i$ handling men også over handling. Det er bl.a. i den forbindelse - stadig set fra de studerendes synspunkt - at der kan tales om aktionsforskning og aktionsorientering, især hvis argumentationen hæftes på Wilfred Carrs og Stephen Kemmis' definition på aktionsforskning fra midten af 1980'erne:

\footnotetext{
"Aktionsforskning er ganske enkelt en form for selvreflekterende undersøgelse, foretaget af deltagerne i sociale relationer for at forbedre rationaliteten og berettigelsen af deres egen praksis, deres forståelse af denne praksis og de situationer, hvori praksis udføres". (Carr og Kemmis, 1985: 162).
}

Samlet set må det understreges at der med hele konstruktionen blev skabt en række nye relationer mellem den enkelte studerende, klyngen af studerende og vejlederne. Man kan også sige, at relationerne mellem den enkelte og fællesskaberne blev udvidet og udviklet med fokus på at udvide og udvikle projektarbejdsformen på RUC. Hovedparten af de studerende gjorde i evalueringen opmærksom på, at såvel det faglige som det sociale udbytte af "Antologiprojektet" havde været større end ved det gængse og enkeltstående projektforløb på RUC. 


\section{Nogle udfordringer i projektet}

Projektet/eksperimentet har selvfølgelig ikke været uden problemer og udfordringer, men generelt har der blandt de studerende været en grundlæggende tilfredshed med forløbet. $82 \%$ anfører således, at de mener projektet bør fortsætte i de kommende semestre. De fleste mente, det havde været spændende, men der er også en række udfordringer til fremtiden. De studerende syntes at:

Vejlederrollen burde nydefineres og i høj grad ekspliciteres, fordi projektet bryder med den traditionelle vejlederrolle på RUC, hvor en enkelt vejleder er tilknyttet en enkelt projektgruppe. Det har ikke været tilfældet i dette forløb, hvor en vejleder har været tilknyttet en klynge og dermed har skullet vejlede både i forhold til klyngen og i forhold til casegrupperne. Det giver en række udfordringer, som der i fremtiden skal arbejdes med. De studerende påpeger i evalueringen, at der bør være mere fokus på det faglige og det skrevne. De mener vejledernes rolle i den fælles klyngevejledning i højere grad bør være som vidensudvikler. Altså: Vejlederne skal i højere grad være i stand til at komme med inspirerende fælles indspil til faglig udvikling f.eks. gennem forelæsninger af mere almen karakter og gennem forskellige former for workshops og temaseminarer. Man kunne også sige, at vejlederne i den forbindelse i højere grad skal være ressourcepersoner. Ekspliciteringen af alt dette skal ske meget tidligt i forløbet.

Linjerne mellem den enkelte og det fxlles har fået nye rammer, og dette burde tydeliggøres for de studerende meget tidligt i projektforløbet. Det er vigtigt, at dette videreformidles til kommende forløb af lignende karakter. Altså: Relationerne mellem den enkelte, det fælles og eksamen har fået nye rammesætninger, og dette skal ekspliciteres. Det samme gælder relationerne mellem vejlederne: F.eks. ville det ifølge de studerende være en god idé, at vejlederne er afklarede på fælles forventninger til de enkelte dele i "Antologiprojektet".

Kompetencer: De studerende er stort set enige om, at projektet har givet dem gode kompetencer i bredden. De mener samtidig, at det er en fremtidig udfordring også at komme mere i dybden. Altså skal der arbejdes mere intensivt med relationerne mellem processen i projektet og den faglige dybde.

Kritiske kommentarer og diskussioner af projektet kunne godt have fået mere plads i eksperimentet.

Mange studerende har savnet dette. Der kan i den forbindelse henvises til Etienne Wenger, som ser praksisfællesskaber som udspændt mellem gensidigt engagement, fælles virksomhed og fælles repertoire. Det skal understreges, at ingen af delene hverken hos Wenger, i virkeligheden eller i det gennemførte projekt/eksperiment er 
ukomplicerede. Tværtimod er det en realitet, at et praksisfællesskab hverken er "en havn af samhørighed eller en $\varnothing$ af fortrolighed isoleret fra politiske og sociale relationer. Uoverensstemmelse, udfordringer og konkurrence kan være måder at deltage på. Som deltagelsesform afslører oprør ofte et større engagement end passiv konformitet". (Wenger, 2004: 94).

Det betyder i al sin enkelthed, at den kritik, som udvikles gennem et eksperiment, bør have stemme, vægt og gennemslag, fordi udfordringerne i denne sammenhæng får liv og får lov til at leve. Det er centralt at lytte til dette.

Hertil kommer, at flere studerende synes, at der har været et for voldsomt empiripres i eksperimentet. Dette er dog ikke en kritik af eksperimentet som sådant - snarere af studieordningen.

Som afrunding og delvis rammesætning omkring en udvikling af antologieksperimentet ved RUC et citat af Wenger, og en udtalelse fra en af de studerende, der indgik i "Antologiprojektet", samt en samlende pointe fra en af censorerne ved eksamen:

"Da gensidigt engagement ikke kræver homogenitet, er en fælles virksomhed ikke ensbetydende med enighed i umiddelbar forstand. I visse fællesskaber kan uenighed ligefrem blive opfattet som en produktiv del af virksomheden. Virksomheden er ikke fælles i den forstand, at alle mener det samme eller er enige om alting, men ved, at den er forhandlet i fællesskab". (Wenger, 2004: 96).

"Vi har arbejdet ud fra et fælles emne, og derfor har arbejdet i casen været retningsbestemt - ikke af en problemformulering som normalt, men af det bredere tema. Det har været en lettelse og sparet os tid. Herudover gør sammensætningen af de forskellige cases i en samlet antologi, at vi kan diskutere vores stof på en meget dybere måde, og vores arbejde føles mere samfundsrelevant end hvis, vi havde beskæftiget os med en enkelt case". (En studerendes kommentar i spørgeskemaundersøgelsen).

"De har bearbejdet materialet på tværs af cases og fået en bredere forståelse af temaet, fordi de kunne tage udgangspunkt i fire cases empiri, der var forskellige. De kunne se flere metoder og teorier i brug ud over dem, de selv havde anvendt og gøre sig overvejelser over, hvad andre teorier og metoder kunne have bragt deres case. De har kunnet opsamle og lave fælles konklusioner på tværgående emner". (En censors kommentar i spørgeskemaundersøgelsen). 
Som allerede anført mente mere end $80 \%$ af de studerende, at "Antologieksperimentet" havde været en positiv oplevelse, og at det burde føres videre i de kommende semestre. Det er efterfølgende blevet vedtaget i studienævnet, at "Antologiformen" nu er den form, undervisningen ved K1-modulet ved Arbejdslivsstudier udspændes omkring.

Søren Dupont: 58 år, ph.d. i Idéhistorie og cand.mag. i Kulturarbejde og -formidling. Har i mere end 30 år arbejdet ved forskellige universiteter, de sidste 15 år som lektor ved RUC $i$ PAES. Søren Dupont og Cxcilie Saul har senest publiceret bogen Hvorfor RUC? - Derfor RUC!, som kan hentes via UniPæds hjemmeside under "Publikationer". Brug følgende link:

http://www.ruc.dk/fileadmin/assets/paes/Unipaed/Hvorfor_RUC_derfor_RUC_2011.pdf

Søren Dupont arbejder i øjeblikket på en publikation omhandlende pædagogik og frnomenologi.

\section{Litteratur}

Andersen, H. L..(2010). "'Constructive alignment' og risikoen for en forsimplende Universitetspædagogik". Dansk Universitetspædagogisk Tidsskrift, nr. 9. København.

Carr, W., \& Kemmis, S. (1985). Becoming Critical: Education, Knowledge and Action Research. London: Falmer Press.

Saul, C., Larsen, T. A., \& Dupont, S. (2011). Evaluering af Antologieksperimentet ved Arbejdslivsstudier. En alternativ projektarbejdsform på RUC. Roskilde Universitet. Roskilde. Tilgængelig på http://www.ruc.dk/fileadmin/assets/paes/Unipaed/Evaluering af Antologieks perimentet paa Arbejdslivsstudier.pdf

Wenger E. (2004). Praksisfallesskaber. Læring, mening og identitet. København: Hans Reitzels Forlag.

Wulf-Andersen, T., Gitz-Johansen, T., \& Rasmussen, K. (2007). "Undervisning i klynger: En artikel om erfaringer med at organisere en form for undervisning, der skaber forbindelse mellem projektarbejde og bredere faglige temaer", Dansk Pædagogisk Tidsskrift, 4. København. 